European journal of American studies

11-1| 2016

Special Issue: Intimate Frictions: History and Literature in the United States from the 19th to the 21 st Century

\title{
A Conversation with Peter Coviello
}

Hélène Quanquin and Cécile Roudeau

\section{(2) OpenEdition}

\section{Journals}

Electronic version

URL: https://journals.openedition.org/ejas/11532

DOI: $10.4000 /$ ejas. 11532

ISSN: 1991-9336

Publisher

European Association for American Studies

Electronic reference

Hélène Quanquin and Cécile Roudeau, "A Conversation with Peter Coviello", European journal of American studies [Online], 11-1 | 2016, document 7, Online since 02 June 2016, connection on 08 July 2021. URL: http://journals.openedition.org/ejas/11532 ; DOI: https://doi.org/10.4000/ejas. 11532

This text was automatically generated on 8 July 2021 .

Creative Commons License 


\title{
A Conversation with Peter Coviello
}

\author{
Hélène Quanquin and Cécile Roudeau
}

Peter Coviello has kindly agreed to have a conversation with us via email about the questions we have been discussing in our research group "History and Literature" based at the Sorbonne Nouvelle and Université Paris-Diderot. Peter Coviello is Professor of American Literature at the University of Illinois at Chicago. He is the editor of Walt Whitman's Memoranda During the War (2004) and the author of Intimacy in America: Dreams of Affiliation in Antebellum Literature (2005) and Tomorrow's Parties: Sex and the Untimely in NineteenthCentury America (2013). With Jared Hickman, he co-edited a 2014 special issue of American Literature entitled "After the Postsecular."

2 Hélène Quanquin and Cécile Roudeau: Our research group has been questioning the frontier between history and literature in the wake of recent works by French scholars, among whom, in particular, Ivan Jablonka's L'Histoire est une littérature contemporaine: Manifeste pour les sciences sociales[History As Contemporary Literature: A Manifesto for Social Sciences](2014). In this book, which follows and should be read as a more personal counterpart to a previous book of "memoirs" about his grandparents who died in Nazi camps, Histoire de ces grandsparents que je n'ai jamais eus [(Hi)story of Those Grandparents I've Never Had] (2012), Jablonka reflects on his own practice as both historian and writer. Jablonka's way of writing may be described as reflexive in two senses: because it is an autobiographical text, and also in the sense that the author is highly aware of the power of literariness, more specifically of literary fiction, to invent the "true" lives of those grandparents he never met. Jablonka's diptych can be considered as a methodological manifesto exhorting us to stop thinking (and doing) inside the disciplinary boxes of "history" and "literature." It encourages historians to acknowledge that fiction and literariness are constitutive of their practice. Ultimately, it aims for what Jablonka calls "creative history" (L'Histoire est une littérature contemporaine, 19), i.e. a 
practice that capitalizes both on empathic proximity and scientific distance. In short, Jablonka and others appeal for a deregulation of knowledge and for practices that would acknowledge overlaps, frictions, and fruitful cross-pollinations without doing away with singularities.

з In the United States, as Hélène Cottet argues in her contribution to this issue, the great divide between history and literature never really happened. At the turn into the twentieth-century, when disciplinary thinking was established, "American Literature" was not yet constituted as a discipline per se; it only emerged as a sub-discipline within English departments belatedly, in the 1920s, and "under the aegis of literary history" (Stokes 17). Later on, the New Critical project that became dominant by the 1940s developed alongside the interdisciplinary venture of the American Studies movement.

4 Your own work has struck us as part of such active unsettling of disciplinary borders-both topically and methodologically.

- To what extent has the question of the uneasy relationship between literature and history arisen in your work? And if so, in what terms?

- Would you relate your work to a particular moment in literary criticism? To a particular generation of critics?

- To what extent have your topics-sexuality and race, together or separately -engendered a critical method that engaged the interrelation of the method (s) of the historian and the method(s) of the literary critic, and possibly your capacity as well as writer and lover of words? To what extent do you think this is also true of the texts you study and more generally speaking of nineteenth-century American literature?

5 Peter Coviello: I especially appreciate what you say about the differences between the intellectual trajectories of American literary study as it transpires in Europe and in the United States. That seems to me right and, knowing as little as I do about the unfolding of American Studies in non-North American contexts, very intriguing. So when you ask about the extent to which "the uneasy relation between literature and history" has been important to my work, I'm struck by the different sort of inflection the question had, for me, when I was taking it up most directly.

6 I do think of myself as belonging to, if not a particular generation of critics, a loose cadre. I think of us as scholars who came of intellectual age in the 1990s and, in the face of the questions and texts that fascinated us, were trying to find modes of approach that might shake themselves loose a bit from what were becoming, by then, the more habituated movements of new historicist criticism. This was not because we-or I should probably be saying, I-had any wish to dismiss New Historicism, under the rubric of which a great wealth of absolutely essential work had transpired. For me, the desire was rather to find a path to some mode of scholarly address that was maybe a little less beholden to the routines of new historicist collation- to an understanding of Fredric Jameson's famous injunction about 
historicizing as, basically, a demand to find some set of nonliterary "discourses" and then to place them in relation to contemporaneous texts, which might then be understood as resistant in respect to those discourses, or acquiescent, or some mix thereof. ("Kinda subversive, kinda hegemonic," as Eve Kosofsky Sedgwick quipped in deft summary of this gestalt.) ii In large measure because of the people I was being taught by and found myself in conversation with, this seemed to me a method that, in practice, under-read both Jameson and Michel Foucault, whose work was as important and unlocking to me as anyone's.

7 The thing is, though, in part because I was from the first interested in questions about the shifting terrain of the erotic-in sex, in the intimate life of race, in queer politics - the pressing antinomy, to me, was not literature v. history but, far more dramatically, psychoanalysis and historicism. I can remember expending a lot of intellectual effort trying to work out how my own intellectual allegiances, which were to genealogical critique in the mode of Foucault but also to the possibilities of Freudian psychoanalysis in the key of Adam Phillips and Leo Bersani and Jacqueline Rose, might be made to cohere.

8 The study of sex and the intimate life of race seemed to me hard to undertake without an approach that figured out how to sacrifice the theoretical richness of neither the genealogical nor the psychoanalytic tradition. And, then as now, queer work was hugely enabling to me. I bet you can see where this is going: I am far from the only person my age whose sense of the possibilities for criticism was revolutionized by Eve Kosofsky Sedgwick. I found in her both a critic passionately invested in politics and in history but not quite conventionally historicist, and also someone committed to the thorniness, the nonnegligible density, of primary texts. Or rather, committed to the unexpended critical and, explicitly, political consequences of textual intricacy. On the first point: I can remember reading Epistemology of the Closet (still I'd say one of the most urgently teachable books in the theory canon) and thinking that here was a critic who was at every point interested in the history of sexuality, and the effects of power that course through it, but whose practice was at quite a distance from the routines of collation I was mentioning earlier, that toggling between authors and some extra-literary discourse that might be named "context." Her method was different and, to my eyes, so much more conceptually rich, attuned as it was to what history made and what it lost or invisibilized; and attuned, too, to the fractious, ambivalent, many-textured relations between texts and the horizoning facts of their historical emplotment. Sedgwick modeled for me a way to read texts not as windows on a period nor as exemplifications of a given politics or its paradoxes but (and this is something I tried hard to articulate in my first book) as vehicles for an unruly range of dispositions toward what the critic might incline to name "history." And that unruliness, for Sedgwick, was a matter very much involved in literary form, in style. I can remember reading a passage where she upbraided a critic for essentially condescending to a given author-for rending invisible what 
she called "the formal and stylistic agency" of that author's texts-and feeling a thrill almost illicit in its intensity. Here's what that moment said to the grad-student-me: do not condescend to the authors you read. Do not presume your own historical and political greater-knowingness; doing so will prevent you from taking requisite great care with how intricately texts are asking you to think problems, how forcefully they are asking you to pose and consider the matters you bring to them. This was for me never an injunction not to critique-Sedgwick was too good a reader of Foucault to have indulged in anodyne belle-lettrism-but an insistence on the often fantastic conceptual power of texts themselves. It came to me, and I think many another, as an injunction to take critical heart from our objects. Which, inarticulately smitten by poems and novels and such as I often was, was great news for me.

9 So as I tried to work my way toward what felt like an adequately lively account of texts and authors I found pretty inexhaustibly compelling, and toward what Sedgwick called "useful generalizations" about queer sex and the intimate life of race. I took heart from critics whose investment in like questions led them afield of the more routinized contextualizing procedures of historicism but not necessarily away from history - critics, I mean, who used literature as a sort of entry-point into what I took to be more capacious accounts of what counts as history, and who might encounter "history" as something other than (as I put it in the introduction to Intimacy in America) "a colloquy of legible codes: as ideology, as structure, as discourse." These were critics who taught me how to think historically while remembering that "history" is something other, and something more, than what condenses into discourse. Sedgwick and, with her, Hortense Spillers (still, I think, one of the greatest, most searching, and methodologically nimble critics working in the last 30 years) were for me the guiding lights in this pursuit, the ones to whose examples I most aspired and still aspire. But there were others, like Mark Seltzer (who was my teacher at Cornell) and Claudia Johnson and Lauren Berlant. Later, the influences of this fomenting moment would work themselves out in the scholarship of a wide range of critics, and these would be the people with whom I most wanted my own work to be in dialogue. I'm thinking of scholars like Kathryn Bond Stockton and Elizabeth Freeman and José Esteban Muñoz and Dana Luciano, to name only a very few of the people who taught me how to navigate the questions you raise about literature and history.

10 H. Q. \& C. R.: Time and textuality are at the heart of your work, and in your introduction to Tomorrow's Parties, you relate the notions of "earliness" and "illegibility." If we understand you correctly, earliness refers to the not-yet-categorized, the not-yet-disciplined that is the privileged terrain of mid-to-late nineteenth-century American literature. Being deprived (yet) of words that will later on put labels on experiences, the texts you are reading exist in the twilight zone of indetermination, "obliquity," "evasion," "extravagance" that is 
(Hawthorne is nodding from the "somewhere else" where he abides) the territory of fiction.

- Is such definition of literature to be historicized? In other words, is literature or the literary as such to be understood, or rather experienced, as what structurally eludes the imperative of legibility-whereas history, and the social sciences more generally, abide by a code of legibility? Or is this opening of an erotic space of infinite interpretation an effect of our own position as twenty-first century readers who know the history of the "great separation" and the disciplinary turn of the beginning of the twentiethcentury?

- To what extent does the illegibility of the literary question our positions as critics, as scholars? How do you read a text that resists "legibility"? How do you see the articulation between "literary imaginings of sexuality" (Tomorrow's Parties, 4) and discourses on sexuality?

- As Ivan Jablonka asks in L'Histoire est une littérature contemporaine, "can we imagine texts which are both history and literature" ("Peut-on imaginer des textes qui soient à la fois histoire et littérature?" [7])?

- Does standing for the principle of illegibility of the literary provide a way, for you, to reclaim the politics of literature "as literature," to quote from Jacques Rancière (4)? Or, more accurately maybe, to move in the direction of Lauren Berlant's literary "juxtapolitical"?

${ }_{11}$ P. C.: I love what you say here about Hawthorne, abiding in his citizenship "somewhere else." I wish I'd thought to make that a part of the last book! As for "earliness": I think I most meant it to refer to the vexed, unstable, to me beguilingly hard-to-narrate position of erotic life -of what would later travel under the name "sexuality" - in mid- and later-nineteenth-century America. My sense was that the very notion of sexuality, which comes into new coherence at the end of the century, had made discerning the errancy of erotic life before that moment of crystallization a tricky sort of endeavor.

${ }_{12}$ Nineteenth-century erotic life, when looked at from within the epistemological horizon of "sexuality," seemed full of weirdnesses and illegibilities. (There is Thoreau, for instance, who imagines fishing as continuous with a sexual practice like masturbation...) I should say I was ballasted in this sort of formulation by great work like that of Virginia Jackson, who in Dickinson's Misery is writing less about the illegibility of the literary as such-though I think there's a venerable deconstructive critical tradition that might tease out exactly such a possibility-than about how certain hardened taxonomies (most crucially for her: "lyric") play a kind of havoc with our ability to pay a fine-grained sort of attention to the unruliness, the hectic clamoring diversity, of nineteenth-century literary practices, later to be organized under the sign "lyric." This is, to say the least of it, a "historicized" approach to literature but one that begins in the premise that our conceptual frameworks (what Lévi-Strauss calls "the historian's code"iv) may need to be shaken up, loosened and recalibrated, in the course of their encounter with the destabilizing force of certain objects. I'm not 
sure this is an argument on behalf of "the politics of literature as literature"-I can imagine good arguments and bad arguments under such a banner-so much as it is a way of speaking up for what we might think of as the marvelously estranging power of the texts we work with and through. I'm interested in what happens when we encounter objects against which our conceptual frameworks seem to reach and strain, to struggle and, sometimes, to break. This is only one of the ways what we decide to call "literature" can have a political force-that is, in its capacity to make strange the systems of thought we bring to them, and so to torque those systems into recalibrated, more capacious versions of themselves, in which new possibilities might gain traction, for thought but not only for thought. (For contestation, refusal, recognition, affiliation...) You can see this happening all the time in great criticism. Think of how reading [Frederick] Douglass enjoins Spillers, in "Mama's Baby, Papa's Maybe," to crack open the Oedipal scenarios of Freudian psychoanalysis and reshape them around subjectivities not only sexed and gendered but, in simultaneity, raced; or how Sedgwick's encounters with James push her similarly away from what she calls "the theoretical parsimony of the Oedipal scenario" and out toward a different, and so differently political, conceptualization of relationality itself; ${ }^{v}$ or of the ways Muñoz's engagements with performance pieces by artists like Marga Gomez and Vaginal Davis, in his indispensable Disidentifications, issue in a politics that all at once borrows from, critiques, and expands queer and minoritarian paradigms of identity and being. We could easily multiply our examples, and I suspect each of us carries around within us a roster of texts, a kind of secret syllabus, that have accomplished for us this sort of enlarging, disorienting work.

13 Again, as I come to it at least, this is a project with roots in queer theory, both in its attunement to what Muñoz asks us (via [Ernst] Bloch) to think of as the utopian affordances of the "not-yet" but also in its allegiance to what Michael Warner calls the ethics of queer life inside a large-scale often informal process of world-making. I'm thinking of that mode of world-making that, as I say at the end of Tomorrow's Parties, "specializes in the multiplication of possibilities for intimate life, in a turbulent, risky, always-unsettled expansion of the roster of forms of connection in which one might find joy, solace, replenishment, and, not least, sexual pleasure."vi This is a project that values expansion, modulation, improvisation, becoming, and it strikes me that what I've called the estranging force of literature can aid and abet it very much indeed. Sedgwick writes, in Epistemology of the Closet, of the "shifting interfacial resistance of 'literature itself' to 'theory'" as productive of a "reservoir of unrationalized nonce-taxonomic energies," vii and I've always heard in that gesture not any derogation of theory, or subtending of "history" to "literature," but an account of one kind of political possibility for literature and its close explication, keyed here to the expansive imaginative project of queer world-making. 
14H.Q \& C.R.: In Tomorrow's Parties: Sex and the Untimely in Nineteenth-Century American Literature, time, textuality, and the question of legibility also underlie your plea for "close reading as doing history" (19). This is a fascinating statement, especially for French critics that have been raised in the tradition of "microlectures" or "explications de texte." As you understand it, "close reading" seems to engage the question of both the reader's and the text's being in time and being in history. What is particularly interesting is the impossible synchronization between the two different "regimes of historicity" (Hartog) of both text and reader-the irrecoverable historicality of the text, on the one hand; the ineluctable belatedness of the reader on the other hand.

- How do you negotiate the reader's belatedness, "going from the present to the past with questions rooted in the present"? ?iii Is this encounter between out-of-sync temporal (and ideological) orders the site of "doing history"?

-Do you see a contradiction between "close textual reading" and "contextualization" and how do you articulate the two?

- Can you explain what you mean when you write in Tomorrow's Parties that your aim is "counterhistorical" and "restorative" (11)?

-Would you say that "close reading," as you understand it, is a queering of history?

15P. C.: I really like what you say about "the impossible synchronization" between readers and the texts they encounter. That's a phrase that very much recalls to me Sedgwick's remark about that "interfacial resistance" cited above and also, more recently, Elizabeth Freeman's beautiful, hugely enabling work on queer temporality. ${ }^{\text {ix }}$ You ask, "Is this encounter between out-of-sync temporal (and ideological) orders the site of 'doing history'?" and my own short answer is, YES, precisely. Or to put it less elegantly than you have, this gap-this mutual estrangement-seems to me to induce an encounter in which neither site, the literary or the historical, is taken for granted in its coherence or referential clarity, but finds itself seized in the midst of its dialectical entanglement with the other. So that the point, for me at least, isn't to produce some sort of positivist account that says, This, not that, is what happened then. Rather, the hope is to shake loose some occluded ways of telling the story of a particular era, a particular set of texts, or a particular conceptual formulation, in the hopes that those new stories might be unlocking or enlarging or in some way usefully clarifying.

16I understand some of the work of Tomorrow's Parties to be counterhistorical and restorative inasmuch as I hoped to bring into relief some of the ways of imagining erotic life that these writers seemed to me to offer but which had been lost in the modes of discursive contextualization to which they had commonly been subject. Close reading, then, may or may not be a queering of history-and honestly I feel a little uneasy about "queer" as transitive verb, only inasmuch as it seems to presume to know in advance what it would 
mean to make something queer, or queerer, and not knowing in advance what form sex might take seems to me much of the force of "queer" in the formulations to which I'm most indebted. But it can be, I think, a way of thickening history: of expanding the range of stories we tell about a place or text or concept, of trying out an expanded repertoire of conceptual possibilities, or of contributing to the project of making what counts as "History" "fatter," as Kathryn Bond Stockton has it. ${ }^{x}$

${ }_{17}$ I should say this is part of what I find so exciting about Americanist work at just this moment. It strikes me as an astonishingly rich time to be doing this work-rich, I mean, both in the breadth of remarkable scholarship being undertaken and also in the conceptual possibilities opening themselves up to new engagement. There are just now so many stories of the nineteenth century we are only beginning to learn how to tell. The emergence of secularism in concert with a hegemonic liberalism and the vast pluralization of religious practice; the solidification of a regime of biopower in a settler-colonial United States; the unfolding of a global imperial project rooted in an American whose racial imperatives, both aligned and misaligned to European models, make for consequential differences: these are, again, stories we are only beginning to learn how best to conceptualize, how to conceptualize with maximal synthesizing power. I think of the range of scholars taking up these problems-the queer theorists I've mentioned like Luciano and Freeman but also Jordan Stein, Tavia Nyong'o, Kyla Wazana Tompkins, scholars of secularism like John Modern and Jared Hickman and Justine Murrison, theorists working the interstices of biopower and empire like Raúl Coronado, Caleb Smith, Monique Alleweart, Hester Blum, and Mark Rifkin, and then too the abundance of younger scholars doing outrageously strong work across all these frameworks, like Zakkiyah Iman Jackson and Kyla Schuller and Chris Taylor and Greta LaFleur-I think of this work, and these writers, and I feel a pretty large-scale gratitude to be working in the field right at this vibrantly unsettled moment.

\section{BIBLIOGRAPHY}

Berlant, Lauren. The Female Complaint: The Unfinished Business of Sentimentality in American Culture. Durham, NC: Duke UP, 2008. Print.

Coviello, Peter, ed. Walt Whitman's Memoranda During the War. Oxford: Oxford UP, 2004. Print.

---. Intimacy in America: Dreams of Affiliation in Antebellum Literature. Minneapolis: University of Minnesota P., 2005. Print. 
---. Tomorrow's Parties: Sex and the Untimely in Nineteenth-Century America. New York: NYU Press, 2013. Print.

---, and Jared Hickman eds. "Introduction: After the Postsecular." American Literature 86.4 (2014): 645-654. Print.

Freeman, Elizabeth. Time Binds: Queer Temporalities, Queer Histories. Durham: Duke UP, 2010. Print.

Hartog, François. Regimes of Historicity: Presentism and Experiences of Time [Régimes d'historicité: Présentisme et expériences du temps]. New York: Columbia UP, 2015. Print.

Jablonka, Ivan. L'Histoire est une littérature contemporaine: Manifeste pour les sciences sociales. Paris: Seuil, 2014. Print.

---. Histoire de ces grands-parents que je n'ai jamais eus. Paris: Seuil, 2012. Print.

Jackson, Virginia. Dickinson's Misery. Princeton: Princeton UP, 2005. Print. Jameson, Fredric. The Political Unconscious: Narrative as a Socially Symbolic Act. Ithaca: Cornell UP, 1981. Print.

Lévi-Strauss, Claude. The Savage Mind [La pensée sauvage, 1962]. Chicago: U of Chicago P, 1966. Print.

Loraux, Nicole. "Éloge de l'anachronisme en histoire," Le Genre humain 27, 1993, 23-39, in Les Voies traversières de Nicole Loraux. Une helléniste à la croisée des sciences sociales. Paris: EspacesTemps/ Les Cahiers Clio, 2005, 131; quoted in Frédérique Fleck, "Les historiens et l'anachronisme." Web. http:// www.fabula.org/atelier.php?Anachronisme et historiographie.

Muñoz, José. Disindentification: Queers of Color and the Performance of Politics. Minneapolis : University of Minnesota P., 1999. Print.

Rancière, Jacques. The Politics of Literature [Politique de la littérature, 2006]. Malden, MA: Polity, 2011. Print.

Sedgwick, Eve Kosofsky. Epistemology of the Closet. 1990. Berkeley: University of California P., 2007. Print.

--.."Queer Performativity: Henry James's The Art of the Novel," in GLQ: Gay and Lesbian Quarterly 1. 1 (1993): 1-16. Print.

---. Tendencies. Durham, NC: Duke UP, 1993. Print.

Spillers, Hortense J. “Mama's Baby, Papa's Maybe: An American Grammar Book." Black, White, and in Color: Essays on American Literature and Culture. Chicago: Chicago UP, 2003, 203-229. Print.

Stockton, Kathryn Bond. The Queer Child, or Growing Sideways in the Twentieth-Century. Durham, NC: Duke UP, 2009. Print.

Stokes, Claudia. Writers in Retrospect: The Rise of American Literary History, 1875-1910. Chapel Hill: University of North Carolina P, 2006. Print.

Warner, Michael. The Trouble with Normal: Sex, Politics, and the Ethics of Queer Life. New York: The Free Press, 1999. Print. 


\section{NOTES}

i. Editors' note: see Jameson, 9.

ii. Editors' note: see "Queer Performativity," 15.

iii. Editors' note: see Intimacy in America, 16.

iv. Editors' note: see Levi-Strauss, 259.

v. Editors' note: see Tendencies, 78.

vi. Editors' note: see Tomorrow's Parties, 205.

vii. Editors' note: see Epistemology of the Closet, 24.

viii. "[A]ller du présent vers le passé avec des questions du présent" (our translation) (Loraux, 131).

ix. Editors' note: see Elizabeth Freeman's Time Binds: Queer Temporalities, Queer Histories.

x. Editors' note: see The Queer Child, or Growing Sideways in the TwentiethCentury, 39.

\section{AUTHORS}

\section{HÉLÈNE QUANQUIN}

Université Sorbonne Nouvelle

CÉCILE ROUDEAU

Université Paris Diderot 